\title{
Broken Coronary Stent Catheter Retrieval Percutaneously Case Report and Literature Review
}

\author{
Evliya Akdeniz, Baris Yaylak, Gönül Zeren, Ilhan Ilker Avci, Baris Simsek, Tolga Onuk, Can Yücel Karabay \\ Department of Cardiology, Dr. Siyami Ersek Thoracic and Cardiovascular Surgery Training and Research Hospital, Istanbul, Turkey \\ ORCID: \\ Evliya Akdeniz: https://orcid.org/0000-0002-4688-7992 \\ Baris Yaylak: https://orcid.org/0000-0001-5863-4039 \\ Gönül Zeren: https://orcid.org/0000-0002-0115-3266 \\ Ilhan Ilker Avci: https://orcid.org/0000-0003-2388-7479 \\ Baris Simsek: https://orcid.org/0000-0001-9412-0035 \\ Tolga Onuk: https://orcid.org/0000-0002-8277-4370 \\ Can Yücel Karabay: https://orcid.org/0000-0002-9653-9048
}

\section{Abstract}

We present a 73-year-old male patient with an unusual complication of a broken coronary stent catheter during percutaneous coronary angioplasty, which was successfully retrieved by balloon trapping and pulling-back method, along with literature review of similar cases.

Keywords: Coronary stent catheter break, percutaneous coronary intervention, percutaneous retrieval

\section{INTRODUCTION}

As interventional cardiology era has been improving and advanced percutaneous coronary interventional procedures have been increasingly performed worldwide, operators might be confronted with some complications. We report a case of coronary stent delivery catheter breaks and its successful retrieval, and we review the literature in this regard.

\section{Case Report}

A 73-year-old male patient was admitted to the emergency department with unstable angina pectoris. After his medical therapy was initiated, diagnostic coronary angiogram was performed. Coronary angiogram revealed a critical stenosis of obtuse marginal branch of the left circumflex artery. Percutaneous intervention to the obtuse marginal branch of the left circumflex artery was mandatory.

The procedure started with punction of the left common femoral artery, which was extremely tortuous. After

Submission: 20-Jan-19 Accepted: 14-Mar-19

\begin{tabular}{|l|l|}
\hline \multicolumn{2}{|c|}{ Access this article online } \\
\hline Quick Response Code: & Website: \\
& \\
http://www.ijcva.com
\end{tabular}

obtaining a successful vascular access, the left main coronary artery was cannulated by a 6-French (6F) EBU guiding catheter (Medtronic Inc., Minneapolis, MN, USA). The patient was anticoagulated by administration of $100 \mathrm{U} / \mathrm{kg}$ unfractional heparin (UFH). Then, the operator passes through the critical stenosis by instrumentality of a soft 0.014 -inch CHOICE floppy coronary guidewire (Boston Scientific, Marlborough, MA, USA). Subsequently, the critical stenotic lesion was predilated successfully with a $2.0 \mathrm{~mm} \times 20 \mathrm{~mm}$ predilation balloon (Invader, Alvimedica Medical Technologies, Turkey) at 12 atmospheric (atm) pressure. Following successful predilation, the operator decided to proceed to the next step, which was implantation of a drug-eluting coronary stent (PROMUS Element, Boston Scientific, Marlborough, MA, USA). Although the whole delivery catheter was inside the guiding catheter, the stent did not reach the critical lesion.

Address for correspondence: Dr. Evliya Akdeniz, Dr. Siyami Ersek Thoracic and Cardiovascular Surgery Training and Research Hospital, Istanbul, Turkey. E-mail: evliyakdeniz@gmail.com

This is an open access journal, and articles are distributed under the terms of the Creative Commons Attribution-NonCommercial-ShareAlike 4.0 License, which allows others to remix, tweak, and build upon the work non-commercially, as long as appropriate credit is given and the new creations are licensed under the identical terms.

For reprints contact: reprints@medknow.com

How to cite this article: Akdeniz E, Yaylak B, Zeren G, Avci II, Simsek B, Onuk T, et al. Broken coronary stent catheter retrieval percutaneously case report and literature review. Int J Cardiovasc Acad 2019;5:99-102. 


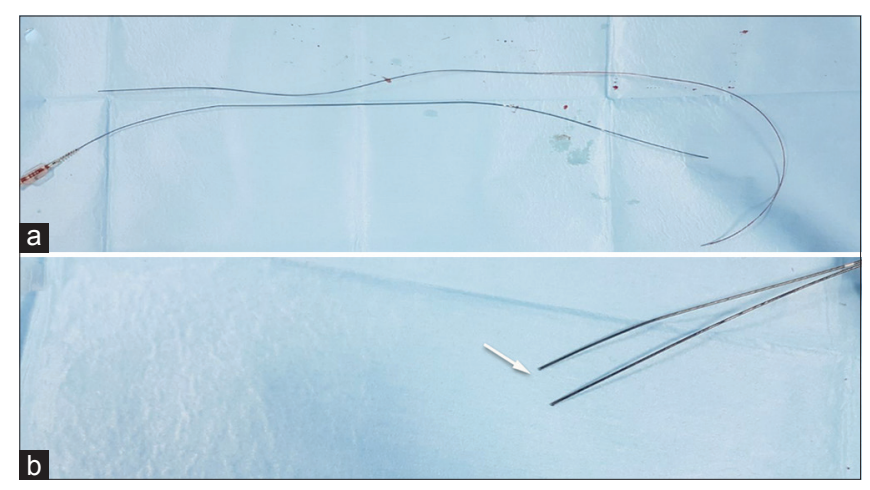

Figure 1: (a) Two broken parts of the whole coronary stent catheter. (b) The site of catheter break (white Arrow)

Suddenly, it was realized that while it was pushed forward, the delivery catheter broke into halves in the guiding catheter because of the extremely tortuous vascular access. One of the broken parts of the delivery catheter was totally inside the body, and the other part was partially in the guiding catheter and its hub was out of the guiding catheter. The operator pulled back the distal part of the broken delivery catheter out of the body [Figure 1]. After that, a $2.5 \mathrm{~mm} \times 20 \mathrm{~mm}$ coronary predilation balloon catheter (Invader, Alvimedica Medical Technologies, Turkey) was inserted into the guiding catheter and passed by the proximal half of the broken stent delivery catheter. By the help of inflation coronary balloon inside of the guiding catheter, the broken part of the stent delivery catheter was trapped inside of the guiding catheter between the predilation balloon and the guiding catheter wall [Figure 2]. It was achieved by withdrawal of the broken part of stent delivery catheter into the guiding catheter by trapping and pulling back the inflated predilation balloon repetitiously [Figure 2]. Just after being sure that the broken part of the catheter was totally in the guiding catheter, all the system was pulled out of the body. After the successfully management of this complication, the left main coronary artery was engaged by a new EBU guiding catheter (Medtronic Inc., Minneapolis, MN, USA). The procedure was continued by crossing the critical stenotic lesion. Finally, a $3.0 \mathrm{~mm} \times 38 \mathrm{~mm}$ drug-eluting coronary stent (PROMUS Element, Boston Scientific, Marlborough, MA, USA) was implanted successfully, and the procedure was terminated without any complication.

\section{Discussion}

Inadvertent retention of coronary hardware such as guidewire, stent or balloon delivery catheter, distal part of atherectomy devices, or dislodged coronary stents due to entrapment or catheter break is very uncommon complication, which leads to myocardial ischemia or infarction, vascular tissue injury, and even death, during percutaneous coronary interventions. Management of such complication requires additional intervention such as surgical or percutaneous intervention. There are several established several retrieval methods for overcoming this unwanted complication with regard to percutaneous intervention. These methods can be summarized

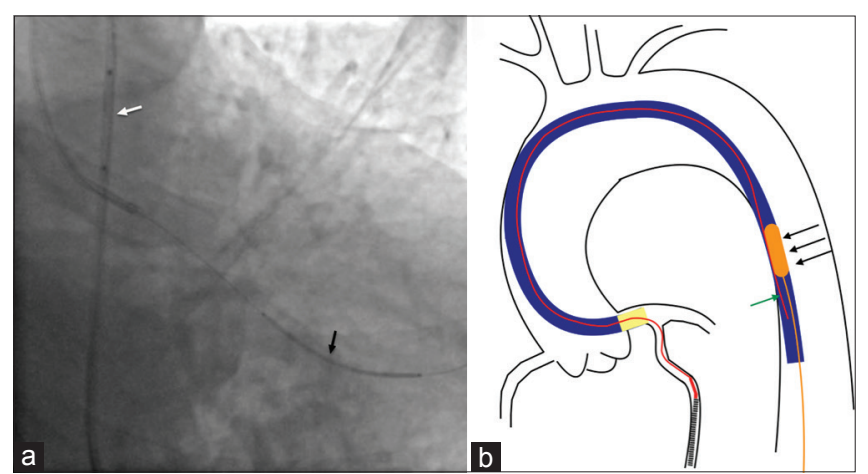

Figure 2: (a) Coronary angiogram view of broken stent delivery catheter in the coronary vasculature. Black arrow shows the coronary stent in the left circumflex artery. Trapping balloon (white arrow) traps the proximal half of the broken catheter. (b) The illustration of the technique. The proximal part of the broken stent catheter (green arrow). Broken catheter is trapped by inflation of balloon (black arrow)

as small balloon technique, two-wire technique, snares, forceps, retrieval baskets, specific retrieval devices, and distal embolic protection devices. ${ }^{[1]}$ Despite these well-established techniques, compensation for such complication can be very challenging sometimes.

In the literature, there are several case reports, including different clinical scenario and various implementation of retrieval technique [Table 1]. Wani et al. ${ }^{[2]}$ reported a case of stent delivery catheter break during percutaneous coronary angioplasty. In this case, the complication was successfully managed by compression of the fractured part of the delivery catheter in the guiding catheter by balloon trapping and removing the entire system out of the body. In the literature, there are several similar cases. ${ }^{[4,6,7,13-15]}$ Another retrieval method was mentioned by Chan et al. ${ }^{[3]}$ In the course of balloon dilation of side branch ostium after main vessel stent deployment, the shaft of balloon catheter accidentally broke, and Chan et al. retrieved the broken part of the catheter by means of using an alligator forceps. An alternative approach for retrieval the foreign bodies in coronary circulation is balloon-supported catheter-assisted retrieval technique. Kunwar et al ${ }^{[5]}$ made a success of restraining of the broken part of balloon catheter between guiding catheter and dilation balloon, followed by ensheathing this broken part into the guiding catheter. A relatively simple method, which was gently withdrawing the entire system as a unit without any additional technique was applied by O'Neill et al.$^{\left[{ }^{[9]}\right.} \mathrm{In}$ another complicated case, after failed attempts by using snare, twowires and balloon techniques to remove a broken intravascular ultrasound catheter in the coronary vasculature, Chang et al..$^{[12]}$ achieved to remove it by the help of using distal embolic protection device. Vimal Mehta et al. ${ }^{[11]}$ achieved to retrieve the distal portion of a broken thrombectomy catheter by means of guiding catheter-supported balloon inflation and pulling-back technique. Similar problems might emerge during advanced percutaneous coronary interventions as well. Imamura et al. ${ }^{[10]}$ reported a case of Rotablator ${ }^{\circledR}$ (Boston Scientific, 


\begin{tabular}{|c|c|c|c|c|c|}
\hline Case & Author & Journal & Publication year & References & Retrieval method \\
\hline 1 & Wani et al. & Korean Circulation Journal & 2010 & {$[2]$} & $\begin{array}{l}\text { Balloon trapping and pulling back } \\
\text { whole assembly }\end{array}$ \\
\hline 2 & Chan et al. & Catheterization and Cardiovascular Interventions & 1999 & [3] & Alligator forceps grasping \\
\hline 3 & Kharge et al. & Texas Heart Institute Journal & 2012 & {$[4]$} & $\begin{array}{l}\text { Balloon trapping and pulling back } \\
\text { whole assembly }\end{array}$ \\
\hline 4 & Kunwar et al. & Journal of Clinical and Diagnostic Research & 2017 & {$[5]$} & $\begin{array}{l}\text { Balloon-supported } \\
\text { catheter-assisted retrieval } \\
\text { technique }\end{array}$ \\
\hline 5 & Kayaert et al. & Cardiovascular Revascularization Medicine & 2013 & {$[6]$} & $\begin{array}{l}\text { Balloon trapping and pulling back } \\
\text { whole assembly }\end{array}$ \\
\hline 6 & Trehan et al. & Catheterization and Cardiovascular Interventions & 2003 & [7] & $\begin{array}{l}\text { Balloon trapping and pulling back } \\
\text { whole assembly }\end{array}$ \\
\hline 7 & Gürbüz et al. & Turk Kardiyol Dern Ars & 2015 & [8] & $\begin{array}{l}\text { Balloon-assisted loop snare } \\
\text { retrieval }\end{array}$ \\
\hline 8 & O’Neill et al. & BMJ Case Reports & 2015 & [9] & $\begin{array}{l}\text { Traction whole system without } \\
\text { using additional tool }\end{array}$ \\
\hline 9 & Imamura et al. & Cardiovascular Intervention and Therapeutics & 2017 & [10] & $\begin{array}{l}\text { Retrieval of a trapped burr using } \\
\text { a balloon and Guideliner }{ }^{\circledR}\end{array}$ \\
\hline 10 & Mehta et al. & The International Journal of Angiology & 2013 & [11] & $\begin{array}{l}\text { Catheter-assisted balloon inflation } \\
\text { and pulling back }\end{array}$ \\
\hline 11 & Chang et al. & International Heart Journal & 2009 & [12] & $\begin{array}{l}\text { Retrieval with embolic protection } \\
\text { device }\end{array}$ \\
\hline 12 & Mehta et al. & Cardiovascular Intervention and Therapeutics & 2014 & [13] & $\begin{array}{l}\text { Balloon trapping and pulling back } \\
\text { whole assembly }\end{array}$ \\
\hline 13 & León Jiménez et al. & Catheter Cardiovascular Intervention & 2017 & [14] & $\begin{array}{l}\text { Balloon trapping and pulling back } \\
\text { whole assembly }\end{array}$ \\
\hline 14 & Fanari et al. & Cardiovascular Revascularization Medicine & 2015 & {$[15]$} & $\begin{array}{l}\text { Balloon trapping and pulling back } \\
\text { whole assembly }\end{array}$ \\
\hline
\end{tabular}

Marlborough, MA, USA) driveshaft fracture and retrieval of entrapped burr by means of squeezing between inflated balloon and GuideLiner ${ }^{\circledR}$ (Japan Lifeline, Tokyo, Japan) and pullback into the guiding catheter.

Sometimes, operators can be encountered similar complications during percutaneous peripheral vascular interventions. Gürbüz et $a l{ }^{[8]}$ experienced and reported such a complication which occurred after peripheral vascular intervention. In this case report, a broken self-expandable peripheral stent cateheter was retrieved succesfully by a techique which icluded a loop snare combined with an inflated balloon.

Consequently, until recently, several retrieval methods have been applied, but none of these methods are like our retrieval technique. On the basis of literature review, our technique, which is balloon trapping and withdrawing the broken hardware and getting it into the guiding catheter before pulling back the whole system, is a unique technique and till now this method is never reported in the interventional era. This method might be safer than other techniques because the broken catheter is completely in the guiding catheter while pulling all systems out of the body. Finally, this method should always be kept in mind in case of a similar complication.

\section{Declaration of patient consent}

The authors certify that they have obtained all appropriate patient consent forms. In the form the patient(s) has/have given his/her/their consent for his/her/their images and other clinical information to be reported in the journal. The patients understand that their names and initials will not be published and due efforts will be made to conceal their identity, but anonymity cannot be guaranteed.

\section{Financial support and sponsorship}

Nil.

\section{Conflicts of interest}

There are no conflicts of interest.

\section{References}

1. Paulus BM, Fischell TA. Retrieval devices and techniques for the extraction of intravascular foreign bodies in the coronary arteries. J Interv Cardiol 2010;23:271-6.

2. Wani SP, Rha SW, Park JY, Poddar KL, Wang L, Ramasamy S, et al. A novel technique for retrieval of a drug-eluting stent after catheter break and stent loss. Korean Circ J 2010;40:405-9.

3. Chan AW, Lohavanichbutr K, Carere RG, Webb JG. Balloon entrapment during side-branch angioplasty through a stent. Catheter Cardiovasc Interv 1999;46:202-4.

4. Kharge J, Sreekumar P, Swamy K, Bharatha A, Ramegowda RT, Nanjappa MC. Balloon-assisted retrieval of a broken stent-delivery system. Tex Heart Inst J 2012;39:644-6.

5. Kunwar BK, Jain P, Ghogare M. Catheter-assisted balloon-supported retrieval of a broken semi-compliant balloon from a coronary artery. J Clin Diagn Res 2017;11:OD06-7.

6. Kayaert P, Sonck J, Semeraro O, Lochy S, Bonnier H, Schoors D. Loss and retrieval of a coronary angioplasty stent balloon. Cardiovasc Revasc Med 2013;14:248-50. 
7. Trehan V, Mukhopadhyay S, Yusuf J, C Ramgasetty U, Mukherjee S, Arora R. Intracoronary fracture and embolization of a coronary angioplasty balloon catheter: Retrieval by a simple technique. Catheter Cardiovasc Interv 2003;58:473-7.

8. GürbüzAS, Öztürk S, Efe SÇ, Yazıcıoğlu MV. Peripheral self-expandable stent catheter fracture: Retrieval of two different components with two different modalities. Turk Kardiyol Dern Ars 2015;43:381-4.

9. O'Neill L, Sowbhaga V, Owens P. Fracture, inflation and floatation embolisation of PTCA balloon. BMJ Case Rep 2015;2015. pii: bcr2014205307.

10. Imamura S, Nishida K, Kawai K, Hamashige N, Kitaoka H. A rare case of rotablator ${ }^{\circledR}$ driveshaft fracture and successful percutaneous retrieval of a trapped burr using a balloon and guideLiner ${ }^{\circledR}$. Cardiovasc Interv Ther 2017;32:294-8.
11. Mehta V, Pandit BN, Trehan V. Retrieval of broken export catheter during primary angioplasty. Int J Angiol 2013;22:185-8.

12. Chang CP, Lin JJ, Hung JS, Pai PY, Hsu CH. Retrieval of dislodged coronary intravascular ultrasound catheter with embolic protection device. Int Heart J 2009;50:121-5.

13. Mehta V, Pandit BN, Yusuf J, Mukhopadhyay S, Trehan V, Tyagi S. Retrieval of impacted broken balloon by balloon inflation in guiding catheter. Cardiovasc Interv Ther 2014;29:252-5.

14. León Jiménez J, Roa Garrido J, Camacho Freire SJ, Díaz Fernández JF. Trapping as retrieval technique to resolve a ruptured and entrapped coronary balloon catheter. Catheter Cardiovasc Interv 2017;90:773-6.

15. Fanari Z, Hamid SA, Hammami S, Mohammed AA, Hammami MB, Qureshi W. Transcatheter retrieval of device entrapment: Management of a rare complication of percutaneous coronary intervention: Case report and literature review. Cardiovasc Revasc Med 2015;16:358-61. 